\title{
FAKTOR-FAKTOR YANG MEMENGARUHI KONFLIK SOSIAL
}

\author{
Suwandi Sumartias dan Agus Rahmat \\ Fakultas Ilmu Komunikasi Universitas Padjadjaran Bandung \\ Jl. Raya Bandung Sumedang Km.21 Jatinangor, Jawa Barat - 45363 \\ Telp, Fax/HP : (022) 7796954, 7794122 ,Hp. 087825968208 dan 08122198354 , \\ email: agusrahmat.fikom@gmail.com dan wandi_sumartias@yahoo.com \\ Naskah diterima tanggal 7 Mei 2013, disetujui pada tanggal 24 Juni 2013
}

\section{FACTORS INFLUENCING OF SOCIAL CONFLICT}

\begin{abstract}
Social conflicts that occur in several areas in Indonesia lately, one of them is caused by the weakness of law certainty. This is feared to threaten the integration of the Republic of Indonesia. This study aims to determine the factors that affect social conflict in Manis Lor village in Kuningan district. The method used the explanatory quantitative methods, the statistical test Path Analysis. The study population was a formal and informal community leaders (village chief, clergy, and youth), and the people who involved in a conflict in Manis Lor village Kuningan regency. The result shows a) There is no significant influence between social identity factors with social conflict anarchist. b) There is significant influence between socio-economic factors with social conflict anarchists. c) There is no significant influence between the credibility factor anarchist leaders with social conflict. d) There is no significant influence between the motive factor with anarchist social conflict. e) There is significant influence between personality factors/beliefs with anarchist social conflict. f) There is significant influence of behavioral factors anarchist communication with social conflict.
\end{abstract}

Keywords: social conflict, anarchist, formal and informal leader.

\begin{abstract}
Abstrak
Konflik sosial yang terjadi di beberapa daerah di Indonesia akhir-akhir ini, salah satunya disebabkan lemahnya kepastian hukum. Hal ini dikhawatirkan akan mengancam integrasi Negara Kesatuan Republik Indonesia. Penelitian ini bertujuan untuk mengetahui faktor-faktor yang memengaruhi konflik sosial di desa Manis Lor Kabupaten Kuningan. Metode penelitian yang digunakan yakni metode kuantitatif eksplanatoris, dengan uji statistik Analisis Jalur. Populasi penelitian adalah tokoh masyarakat formal dan informal (Kepala desa, ulama, dan pemuda), dan masyarakat yang terlibat konflik sosial di desa Manis Lor Kabupaten Kuningan. Hasil penelitian menunjukkan: a) Tidak terdapat pengaruh yang signifikan antara faktor identitas sosial dengan konflik sosial anarkis. b) Terdapat pengaruh yang signifikan antara faktor sosial-ekonomi dengan konflik sosial anarkis. c) Tidak terdapat pengaruh yang signifikan antara faktor kredibilitas tokoh dengan konflik sosial anarkis. d) Tidak terdapat pengaruh yang signifikan antara faktor motif dengan konflik sosial anarkis. e) Terdapat pengaruh yang signifikan antara faktor kepribadian/keyakinan dengan konflik sosial anarkis. f) Terdapat pengaruh yang signifikan antara faktor perilaku komunikasi dengan konflik sosial anarkis.
\end{abstract}

Kata kunci: konflik sosial, anarkis, pemimpin formal dan informal. 


\section{PENDAHULUAN}

Konflik sosial yang anarkis selalu terjadi antarkomunitas (horizontal) dan komunitas dengan para elite birokrasi (vertikal) seolah menjadi potensi yang terus menerus menghantui dan mengancam ketertiban sosial, yang pada gilirannya tak menutup kemungkinan akan mengancam integrasi Negara Kesatuan Republik Indonesia (NKRI).

Konflik berdarah yang terjadi di beberapa wilayah di Indonesia akhir-akhir ini, yaitu konflik antarumat beragama di Kuningan, Pandeglang, Tasikmalaya, Bekasi, dan Temanggung, menunjukkan pada kita semua, betapa rentannya masyarakat Indonesia jatuh dalam tindak kekerasan yang berujung pada perilaku anarkis. Hanya karena perbedaan keyakinan, seorang warga masyarakat rela menganiaya bahkan sampai menghilangkan nyawa sesama. Kondisi ini tentu menimbulkan pertanyaan di hati kita mengapa bangsa yang sejak lama telah dikenal sebagai bangsa yang ramah dan penuh toleransi mendadak berubah menjadi bangsa yang lebih mengedepankan kekuatan otot dibandingkan kekuatan otak untuk menyelesaikan persoalan yang dihadapinya (Anonim, 2011).

Masifnya kekerasan sosial dalam bentuk apapun, sebenarnya representasi dari manusia-manusia tanpa nurani dan akal sehat serta jauh dari peradaban. Egoisme dan arogansi kebenaran atas nama kelompok, kebenaran mayoritas, seringkali menjadi satusatunya cara untuk melegitimasi tindak kekerasan.

Lemahnya penegakan kepastian hukum terhadap kasus-kasus kekerasan sosial yang bersifat massal dan atau melibatkan para elite tertentu, telah memberi ruang toleransi dan pembenaran terhadap munculnya aksi-aksi kekerasan sosial.

Perlu dicermati bahwa konflik sosial anarkis yang berlatar belakang perbedaan agama, budaya, dan atau keyakinan tidak pernah selesai dengan dialog, bahkan dalam dialog seringkali menyisakan berbagai potensi konflik, dominasi serta pembenaran oleh sekelompok yang merasa mayoritas, sehingga kebenaran menjadi semu menurut kacamata mayoritas, dan kondisi inilah yang sering muncul dalam dialog, bukan solusi yang ada, tetapi melahirkan berbagai persoalan baru dan laten.

Pemerintah saat ini, secara resmi hanya mengakui enam agama: Islam, Protestan, Katolik Roma, Hindu, Buddha, dan Konghucu. Meskipun bukan negara Islam, Indonesia adalah yang paling padat penduduknya di dunia yang mayoritas penduduknya muslim. Sebagian besar umat Hindu adalah Hindu Bali, dan sebagian besar umat Buddha di zaman modern Indonesia adalah etnis Cina. Meski sekarang agamaagama minoritas, Hindu dan Buddha tetap menentukan pengaruh dalam kebudayaan Indonesia.

Konflik sosial yang berlatar belakang SARA tumbuh ibarat gunung es, dan layaknya bom waktu yang siap meledak kapan dan di mana saja. Sehubungan dengan persoalan di atas, penelitian tentang faktorfaktor yang memengaruhi konflik sosial di desa Manis Lor Kabupaten Kuningan Jawa Barat melalui studi kuantitatif dengan analisis jalur menjadi sesuatu yang penting dilakukan, mengingat desa Manis Lor merupakan salah satu desa yang mengalami konflik kekerasan karena persoalan keyakinan.

Permasalahannya adalah faktor-faktor apa sajakah yang memengaruhi konflik sosial di desa Manis Lor Kabupaten Kuningan?

Tujuan penelitian ini adalah untuk mengetahui:

1. Pengaruh identitas sosial kelompok terhadap terjadinya konflik sosial yang anarkis;

2. Pengaruh sosial ekonomi terhadap terjadinya konflik sosial yang anarkis;

3. Pengaruh kredibilitas tokoh informal dan formal terhadap terjadinya konflik sosial yang anarkis;

4. Pengaruh motif para pelaku konflik sosial yang anarkis;

5. Pengaruh kepribadian dan keyakinan para pelaku dalam konflik sosial yang anarkis;

6. Pengaruh perilaku komunikasi terhadap terjadinya konflik sosial yang anarkis;

Adapun manfaat penelitian ini adalah 
memberikan masukan kepada pemerintah khususnya Pemerintah Daerah Kabupaten Kuningan agar lebih memerhatikan identitas sosial, sosial ekonomi masyarakat setempat dan juga perlunya memberdayakan tokohtokoh formal dan informal di daerah tersebut, agar konflik-konflik sosial tidak terjadi lagi.

\section{LANDASAN KONSEP}

Perubahan-perubahan sosial, menurut Teori Konflik, diawali oleh konflik yang terjadi pada masyarakat. Sebagai gejala sosial, konflik akan selalu ada, baik antar individu maupun antarkelompok, pada setiap masyarakat. Konflik menyangkut hubungan sosial antarmanusia baik secara individual maupun kolektif. Semua hubungan sosial, menurut Coser, pasti memiliki tingkat antagonisme tertentu, ketegangan, atau perasaan negatif (Johnson, 1990). Hal ini merupakan akibat dari keinginan individu atau kelompok untuk meningkatkan kesejahteraan, kekuasaan, prestise, dukungan sosial, atau penghargaan lainnya. Sementara itu, masing-masing mereka, secara individual ataupun kelompok, di samping memiliki sejumlah kesamaan, juga mempunyai serangkaian perbedaan. Persamaan dan perbedaan tersebut menyangkut jenis kelamin, tingkat pendidikan, pekerjaan, latar belakang budaya, ideologi, cara pandang, cita-cita, kepentingan, dan sebagainya.

Perbedaan-perbedaan seperti itu merupakan sebuah kenyataan sosial yang tak mungkin dihindari. Persamaan dan perbedaan ini, pada tingkat tertentu, ketika satu sama lain saling bertemu dan bergesekan, berpotensi menimbulkan konflik. Kesamaan keinginan atas sesuatu, sementara sesuatu itu merupakan sumberdaya yang langka dan terbatas, maka hal itu akan menimbulkan kompetisi atau perebutan pencapaian keinginan masing-masing. Ketika perbedaan ideologi terjadi antarkelompok, sementara satu sama lain ingin menancapkan pengaruhnya kepada kelompok lain, maka konflik atau perselisihanpun akan terjadi.

Kajian tentang konflik sosial dalam masyarakat, telah banyak dilakukan berbagai lembaga, organisasi maupun perorangan sebagai karya ilmiah. Perspektif konflik, antara lain pandangan Karl Marx, bahwa hubungan sosial merupakan hubungan kelas yang bersifat eksploitatif dan berorientasi pada hubungan konflik. Konflik akan semakin mudah timbul bila interdependensi makin meningkat. Bila interaksi menjadi semakin kerap dan melibatkan berbagai kegiatan dan hal-hal yang semakin luas, peluang untuk munculnya ketidaksesuaian akan semakin besar (Sears, 1985).

\section{Memahami Sifat Konflik Antar Kelompok}

Marx, Dahrendorf, Simmel, dan Coser mengatakan bahwa secara sederhana, konflik adalah pertentangan antara satu individu dengan individu lain, atau antara satu kelompok dengan kelompok lain. Sebetulnya, konflik dapat dilihat dari dua segi. Dari segi positif, konflik dapat mendinamisasikan kelompok-kelompok dalam masyarakat. Konflik dapat memacu bagi terjadinya kompetisi yang sehat, orang berupaya untuk menjadi lebih baik dari yang lainnya. Konflik bisa menjadi tahap awal perubahan sosial. Dari segi negatif, konflik merupakan salah satu masalah yang perlu diatasi. Konflik yang sengit dapat memicu perselisihan dan permusuhan yang tajam, yang mengganggu suasana antarkelompok dalam masyarakat (Johnson, 1986).

Oleh karena konflik di masyarakat merupakan sesuatu yang tak bisa dielakkan, maka yang perlu diketahui adalah apakah konflik itu ada atau tidak ada, tapi bagaimana intensitas dan tingkat kekerasannya, dan dalam bentuk apa konflik itu, apakah menyangkut masalah fundamental atau isuisu sekunder, bertentangan tajam atau sekadar perbedaan pandangan.

Intensitas konflik menunjuk pada tingkat pengeluaran energi dan keterlibatan dari pihak-pihak (kelompok-kelompok) yang berkonflik, sedangkan kekerasan konflik menyangkut alat atau sarana yang digunakan dalam situasi konflik, mulai dari negosiasi hingga saling menyerang secara fisik. Konflik antarkelompok yang menyangkut masalah prinsip dasar (fundamental) akan 
menimbulkan pertentangan antarkelompok yang lebih serius dibandingkan bila masalahnya sekadar bersifat sekunder atau dinilai tak penting (Johnson, 1990).

Konflik dapat dibedakan antara konflik realistik dan konflik nonrealistik. Konflik realistik merupakan suatu alat untuk suatu tujuan tertentu, yang kalau tujuan itu tercapai mungkin akan menghilangkan sebab-sebab dasar dari konflik itu. Sebaliknya, konflik nonrealistik adalah ungkapan permusuhan sebagai tujuannya sendiri (Johnson, 1990). Konflik realistik adalah kompetisi untuk memperoleh sumberdaya langka dan terbatas.

\section{Tinjauan Realistic Conflict Theory}

Realistic

$$
\text { Conflict }
$$

Theory

dikembangkan oleh sejumlah pakar, melalui berbagai studi eksperimen, di antaranya yang sangat menonjol adalah Muzafer Sherif. Teori ini pada dasarnya merupakan teori ekonomi mengenai perilaku antarkelompok. Perilaku antarkelompok adalah hubungan antara dua atau lebih kelompok dan masing-masing anggota kelompok itu. Teori ini memiliki beberapa pandangan, antara lain: (1) bahwa konflik itu pada dasarnya buruk; (2) manusia bersifat egois untuk memaksimalkan keuntungan dirinya; (3) konflik terjadi ketika satu pihak memaksimalkan keuntungan dirinya dan bersentuhan dengan kepentingan pihak lain (Taylor dan Moghaddam, 1994).

Penyelesaian konflik antarkelompok berdasarkan Realistic Conflict Theory, berdasarkan eksperimen Sherif, adalah berada pada tahap terakhir, yakni bagaimana mengubah konflik, pertikaian, atau perselisihan menjadi sebuah bentuk kerjasama. Menurut Sherif, konflik antar kelompok itu akan berubah menjadi kerjasama antarkelompok apabila kepada mereka diintroduksikan superordinate goals secara meyakinkan. Kepada kelompokkelompok yang bertikai perlu diyakinkan bahwa di atas hal-hal yang membuat mereka saling bermusuhan itu, ada hal yang jauh lebih penting untuk dihadapi bersama (Taylor dan Moghaddam, 1994).

Untuk menjembatani kelompokkelompok yang berkonflik itu, diperlukan adanya mediator. Mediator haruslah orang atau lembaga yang dapat diterima oleh semua kelompok, dan mampu mengakomodasi pelbagai kepentingan kelompok. Mediator harus mampu merumuskan superordinate goals sebagai kepentingan bersama semua kelompok, mengajak kelompok-kelompok duduk bersama dalam pertemuan langsung (face to face), pertemuan mana perlu dilakukan beberapa kali.

\section{METODE PENELITIAN}

Metode yang digunakan dalam penelitian tentang faktor-faktor yang memengaruhi terjadinya konflik sosial yang anarkis dan model resolusi di desa Manis Lor Kabupaten Kuningan adalah metode survei eksplanatoris. Di mana variabel penelitian yang diperoleh melalui angket yang ditanyakan kepada responden dianalisis dengan menggunakan analisis kuantitatif dengan uji statistik Analisis Jalur (Path Analysis) terhadap variabel langsung dan tidak langsung dari variabel independen (faktor-faktor yang memengaruhi) terhadap variabel dependen (konflik sosial yang anarkis).

Analisis jalur digunakan untuk mengetahui seberapa besar pengaruh langsung dan tindak langsung dari variabel:

1. Identitas sosial kelompok terhadap terjadinya konflik sosial yang anarkis;

2. Keyakinan terhadap terjadinya konflik sosial yang anarkis;

3. Sosial ekonomi terhadap terjadinya konflik sosial yang anarkis;

4. Kredibilitas tokoh informal dan formal terhadap terjadinya konflik sosial yang anarkis;

5. Motif para pelaku konflik sosial yang anarkis;

6. Kepribadian dan keyakinan para perlaku terhadap konflik sosial yang anarkis;

7. Perilaku komunikasi terhadap terjadinya konflik sosial yang anarkis;

Berdasarkan kerangka pemikiran di atas, disusun model hubungan antar variabel penelitian seperti terlihat pada gambar 1 . 


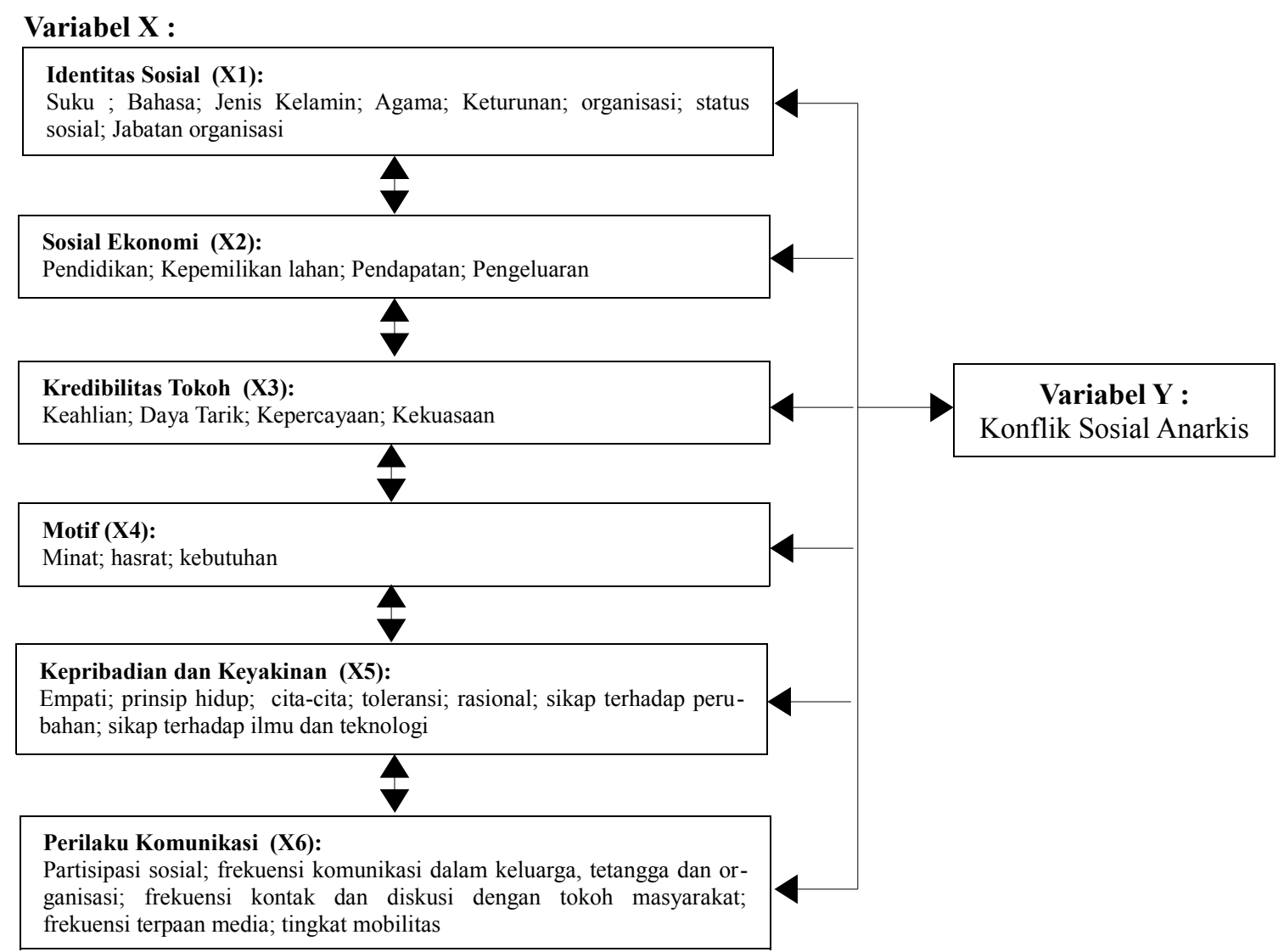

\section{Gambar 1}

Model Hubungan Antar Variabel Penelitian

Tempat penelitian di desa Manis Lor kecamatan Jalaksana Kabupaten Kuningan Provinsi Jawa Barat. Pencarian sampel dalam penelitian ini menggunakan Simple Random Sampling atau sampel acak sederhana, yaitu "untuk menarik sampel seperti ini kita dapat menuliskan semua unsur populasi dalam secarik kertas, kemudian mengundinya sampai kita memperoleh jumlah yang dikehendaki. Unsur-unsur yang jatuh itulah yang menjadi sampel" (Rakhmat, 2007). . Jumlah sampel dihitung dengan menggunakan rumus Slovin (William G. Cochran dalam Prijana, 2005) sebagai berikut :

$$
\mathrm{N}=\mathrm{N} /\left(1+\mathrm{Ne}^{\wedge} 2\right)
$$

Keterangan :

$\mathrm{n}=$ Ukuran sampel,$\quad \mathrm{N}=$ Ukuran populasi, $\mathrm{E}=$ Kelonggaran ketidaktelititan karena kesalahan pengambilan sampel yang ditolerir, yaitu $10 \%$.
Berdasarkan rumus Slovin, maka ukuran sampel yang akan dipakai adalah sebagai berikut $(\mathrm{N}=30, \mathrm{e}=10 \%): \mathrm{n}=30 /(1+$ $30 \square \times(10 \%) \nabla \wedge 2)=23,07$ dibulatkan menjadi 23 orang. Dalam hal ini, jumlah objek penelitian dalam populasi sebanyak 30 $\mathrm{KK}$, warga yang terindikasi terlibat konflik antara Islam dan Ahmadiah, diperoleh jumlah responden sebanyak 23 orang.

\section{HASIL PENELITIAN DAN PEMBAHASAN}

Konflik sosial bisa berlangsung pada aras antarruang kekuasaan. Terdapat tiga ruang kekuasaan yang dikenal dalam sebuah sistem sosial kemasyarakatan, yaitu "ruang kekuasaan negara", "masyarakat sipil atau kolektivitas-sosial", dan "sektor swasta" (Osborne dan Loon, 1998).

Ada sejumlah prasyarat yang memungkinkan konflik sosial dapat 
berlangsung, antara lain:

1. Ada isu-kritikal yang menjadi perhatian bersama (commonly problematized) dari para pihak berbeda kepentingan;

2. Ada inkompatibilitas harapan/kepentingan yang bersangkut paut dengan sebuah objek perhatian para pihak bertikai;

3. Gunjingan/gosip atau hasutan serta fitnah merupakan tahap inisiasi konflik sosial yang sangat menentukan arah perkembangan konflik sosial menuju wujud real di dunia nyata;

4. Ada kompetisi dan ketegangan psikososial yang terus dipelihara oleh kelompokkelompok berbeda kepentingan sehingga memicu konflik sosial lebih lanjut;

5. "Masa kematangan untuk perpecahan";

6. Clash yang bisa disertai dengan violence (kerusakan dan kekacauan).

Faktor-faktor yang diidentifikasi memengaruhi konflik sosial anarkis di masyarakat desa Manis Lor Kabupaten Kuningan Jawa Barat adalah identitas sosial, sosial ekonomi, kredibilitas tokoh, motif, kepribadian, dan keyakinan serta komunikasi. Alat analisis yang digunakan untuk menguji faktor-faktor yang memengaruhi konflik sosial anarkis di masyarakat Kabupaten Kuningan Jawa Barat adalah analisis jalur.

Secara bersama-sama keenam faktor memberikan pengaruh sebesar 79,04\% (nilai $\mathrm{R}^{2}$ ) terhadap konflik sosial anarkis di masyarakat Kabupaten Kuningan Jawa Barat. Sedangkan sisanya sebesar 20,96\% merupakan pengaruh faktor-faktor lain di luar keenam faktor yang diteliti.

\section{Pengaruh Faktor Identitas Sosial Terhadap Konflik Sosial Anarkis}

Hipotesis pertama yang diuji adalah pengaruh faktor identitas sosial terhadap konflik sosial anarkis. Sebagaimana dihipotesiskan bahwa faktor identitas sosial berpengaruh terhadap konflik sosial anarkis. Berdasarkan hasil pengolahan dapat dilihat koefisien jalur dari faktor identitas sosial terhadap konflik sosial anarkis sebesar 0,0643 dengan arah negatif. Artinya semakin kuat identitas sosial yang dimiliki masyarakat akan mengurangi konflik sosial anarkis di masyarakat desa Manis Lor Kabupaten Kuningan Jawa Barat. Kemudian hasil kuadrat dari koefisien jalur sebesar 0,0041 menunjukkan bahwa identitas sosial hanya memberikan pengaruh sebesar $0,41 \%$ dalam mengurangi konflik sosial anarkis di masyarakat desa Manis Lor Kabupaten Kuningan Jawa Barat.

Nilai statitik $t_{\text {hitung }}$ sebesar 0,5415 lebih kecil dari 2,120 yang menunjukkan bahwa hasil pengujian tidak signifikan. Artinya faktor identitas sosial tidak signifikan dalam memengaruhi terjadinya konflik sosial anarkis di masyarakat desa Manis Lor Kabupaten Kuningan Jawa Barat.

\section{Pengaruh Faktor Sosial Ekonomi Terhadap Konflik Sosial Anarkis}

Hipotesis kedua yang diuji adalah pengaruh faktor sosial ekonomi terhadap konflik sosial anarkis. Sebagaimana dihipotesiskan bahwa faktor sosial ekonomi berpengaruh terhadap konflik sosial anarkis. Berdasarkan hasil pengolahan dapat dilihat koefisien jalur dari faktor sosial ekonomi terhadap konflik sosial anarkis sebesar 0,3057 dengan arah negatif. Artinya semakin baik tingkatan sosial ekonomi yang dimiliki masyarakat akan mengurangi konflik sosial anarkis di desa Manis Lor Kabupaten Kuningan Jawa Barat. Kemudian hasil kuadrat dari koefisien jalur sebesar 0,0935 menunjukkan bahwa faktor sosial ekonomi memberikan pengaruh sebesar 9,35\% dalam mengurangi konflik sosial anarkis di masyarakat Kabupaten Kuningan Jawa Barat.

Nilai statitik $t_{\text {hitung }}$ sebesar 2,4746 lebih besar dari 2,120 yang menunjukkan bahwa hasil pengujian signifikan. Artinya faktor sosial ekonomi signifikan dalam mengurangi terjadinya konflik sosial anarkis di masyarakat Kabupaten Kuningan Jawa Barat.

\section{Pengaruh Faktor Kredibilitas Tokoh Terhadap Konflik Sosial Anarkis}

Hipotesis ketiga yang diuji adalah pengaruh faktor kredibilitas tokoh terhadap konflik sosial anarkis. Sebagaimana 
dihipotesiskan bahwa faktor kredibilitas tokoh berpengaruh terhadap konflik sosial anarkis. Berdasarkan hasil pengolahan dapat dilihat koefisien jalur dari faktor kredibilitas tokoh terhadap konflik sosial anarkis sebesar 0,0946 dengan arah negatif. Artinya semakin kuat kredibilitas tokoh di masyarakat akan mengurangi konflik sosial anarkis di masyarakat Kabupaten Kuningan Jawa Barat. Kemudian hasil kuadrat dari koefisien jalur sebesar 0,0089 menunjukkan bahwa kredibilitas tokoh hanya memberikan pengaruh sebesar $0,89 \%$ dalam mengurangi konflik sosial anarkis di masyarakat Kabupaten Kuningan Jawa Barat.

Nilai statitik $t_{\text {hitung }}$ sebesar 0,7003 lebih kecil dari 2,120 yang menunjukkan bahwa hasil pengujian tidak signifikan. Artinya faktor kredibilitas tokoh tidak signifikan dalam mengurangi terjadinya konflik sosial anarkis di masyarakat Kabupaten Kuningan Jawa Barat.

\section{Pengaruh Faktor Motif Terhadap Konflik Sosial Anarkis}

Hipotesis keempat yang diuji adalah pengaruh faktor motif terhadap konflik sosial anarkis. Sebagaimana dihipotesiskan bahwa faktor motif berpengaruh terhadap konflik sosial anarkis. Berdasarkan hasil pengolahan dapat dilihat koefisien jalur dari faktor motif terhadap konflik sosial anarkis sebesar 0,0848 dengan arah positif. Artinya semakin lemah motif yang dimiliki masyarakat akan mengurangi konflik sosial anarkis di masyarakat desa Manis Lor Kabupaten Kuningan Jawa Barat. Kemudian hasil kuadrat dari koefisien jalur sebesar 0,0072 menunjukkan bahwa motif hanya memberikan pengaruh sebesar $0,72 \%$ dalam mengurangi konflik sosial anarkis di masyarakat Kabupaten Kuningan Jawa Barat.

Nilai statitik $t_{\text {hitung }}$ sebesar 0,7003 lebih kecil dari 2,120 yang menunjukkan bahwa hasil pengujian tidak signifikan. Artinya faktor motif tidak signifikan dalam mengurangi terjadinya konflik sosial anarkis di masyarakat Kabupaten Kuningan Jawa Barat.

\section{Pengaruh Faktor Kepribadian dan Keyakinan Terhadap Konflik Sosial Anarkis}

Hipotesis kelima yang diuji adalah pengaruh faktor kepribadian dan keyakinan terhadap konflik sosial anarkis. Sebagaimana dihipotesiskan bahwa faktor kepribadian dan keyakinan berpengaruh terhadap konflik sosial anarkis. Berdasarkan hasil pengolahan dapat dilihat koefisien jalur dari faktor kepribadian dan keyakinan terhadap konflik sosial anarkis sebesar 0,6487 dengan arah negatif. Artinya semakin kuat kepribadian dan keyakinan yang dimiliki masyarakat akan mengurangi konflik sosial anarkis di masyarakat desa Manis Lor Kabupaten Kuningan Jawa Barat. Kemudian hasil kuadrat dari koefisien jalur sebesar 0,4208 menunjukkan bahwa faktor kepribadian dan keyakinan memberikan pengaruh sebesar $42,08 \%$ dalam mengurangi konflik sosial anarkis di masyarakat Kabupaten Kuningan Jawa Barat.

Nilai statitik $t_{\text {hitung }}$ sebesar 4,2271 lebih besar dari 2,120 yang menunjukkan bahwa hasil pengujian signifikan. Artinya faktor kepribadian dan keyakinan signifikan dalam mengurangi terjadinya konflik sosial anarkis di masyarakat Kabupaten Kuningan Jawa Barat.

\section{Pengaruh Faktor Perilaku Komunikasi Terhadap Konflik Sosial Anarkis}

Hipotesis keenam yang diuji adalah pengaruh faktor perilaku komunikasi terhadap konflik sosial anarkis. Sebagaimana dihipotesiskan bahwa faktor perilaku komunikasi berpengaruh terhadap konflik sosial anarkis. Berdasarkan hasil pengolahan dapat dilihat koefisien jalur dari faktor perilaku komunikasi terhadap konflik sosial anarkis sebesar 0,2796 dengan arah negatif. Artinya semakin baik perilaku komunikasi di masyarakat akan mengurangi konflik sosial anarkis di masyarakat Kabupaten Kuningan Jawa Barat. Kemudian hasil kuadrat dari koefisien jalur sebesar 0,0782 menunjukkan bahwa faktor perilaku komunikasi memberikan pengaruh sebesar 7,82\% dalam 
mengurangi konflik sosial anarkis di masyarakat Kabupaten Kuningan Jawa Barat.

Nilai statitik $t_{\text {hitung }}$ sebesar 2,1351 lebih besar dari 2,120 yang menunjukkan bahwa hasil pengujian signifikan. Artinya faktor perilaku komunikasi signifikan dalam mengurangi terjadinya konflik sosial anarkis di masyarakat Kabupaten Kuningan Jawa Barat.

\section{PENUTUP}

\section{Simpulan}

Tidak terdapat pengaruh yang signifikan antara faktor identitas sosial dengan konflik sosial anarkis. Hal ini menunjukkan bahwa identitas tidak begitu memengaruhi konflik sosial anarkis di masyarakat Kabupaten Kuningan, khususnya di desa Manis Lor.

Terdapat pengaruh yang signifikan antara faktor sosial ekonomi dengan konflik sosial anarkis. Hal ini menunjukkan bahwa faktor sosial ekonomi dapat memengaruhi keberadaan konflik di masyarakat Kabupaten Kuningan, khususnya di desa Manis Lor.

Tidak terdapat pengaruh yang signifikan antara faktor kredibilitas Tokoh dengan konflik sosial anarkis. Hal ini menunjukkan bahwa kredibilitas tokoh tidak begitu memengaruhi konflik sosial anarkis di masyarakat Kabupaten Kuningan, khususnya di desa Manis Lor.

Tidak terdapat pengaruh yang signifikan antara faktor motif dengan konflik sosial anarkis. Hal ini menunjukkan bahwa faktor motif tidak begitu memengaruhi konflik sosial anarkis di masyarakat Kabupaten Kuningan, khususnya di desa Manis Lor.

Terdapat pengaruh yang signifikan antara faktor kepribadian dan keyakinan dengan konflik sosial anarkis. Hal ini menunjukkan bahwa kepribadian dan keyakinan seseorang memengaruhi konflik sosial anarkis di masyarakat Kabupaten Kuningan, khususnya di desa Manis Lor.

Terdapat pengaruh yang signifikan antara faktor perilaku komunikasi dengan konflik sosial anarkis. Hal ini menunjukkan bahwa perilaku komunikasi memengaruhi konflik sosial anarkis di masyarakat Kabupaten Kuningan, khususnya di desa Manis Lor.

\section{Saran}

Dalam identitas sosial sebaiknya lebih diperhatikan kembali sebab merupakan bagian dari interaksi sosial yang dapat mengidentifikasi keberadaan suatu konflik. Faktor sosial ekonomi sebaiknya menjadi bahan pertimbangan pemerintah desa setempat dalam hal menanggulangi potensi konflik yang bisa terjadi. Keberadaan tokoh formal dan informal di desa sebaiknya dapat diberdayakan kembali dalam upaya sebagai fasilitator yang bersifat netral bagi penyelesaian konflik yang bisa terjadi.

Motif yang dimiliki oleh orang desa masih terbatas pada aspek keyakinan beragama, maka sebaiknya motif ini perlu dialihkan pada motif-motif lainnya sehingga potensi konflik bisa diminimalisir.

\section{DAFTAR PUSTAKA}

\section{Buku :}

Anonim. (2011). Pusat Studi Pedesaan dan Kawasan. Yogyakarta:UGM.

Johnson, D.P. (1990). Teori Sosiologi: Klasik dan Modern (Jilid II). Terj. Robert M.Z. Lawang. Jakarta: Gramedia.

Prijana. (2005). Metode Sampling Terapan Untuk Penelitian Sosial. Bandung: Humaniora.

Osborne, R. dan B. van Loon. 1998. Mengenal Sosiologi: For Beginners. Ed. Richard Appignanesi. Terj. Siti Kusumawati A. Bandung: Mizan.

Rakhmat, Jalaluddin. (1990). Psikologi Komunikasi. Bandung: Rosda.

Sears, David. O. Dkk. (1985). Psikologi Sosial (Jilid I). Jakarta: Erlangga.

Taylor, D.M. and F.M. Moghaddam. (1994). Theories of Intergroup Relations, International Social Psychological Perspectives. London: Praeger Publishers. 